\title{
Developing an AHP Risk Assessment Model for PPP Projects in Jordan
}

DOI : 10.36909/jer.10543

\author{
Maram Almuhisen ${ }^{1 *}$, Hüseyin Gökçekuş ${ }^{1}$, Tahir Çelik ${ }^{2}$ \\ ${ }^{1}$ Faculty of Civil and Environmental Engineering, Near East University, 99010, North Cyprus, \\ TRNC. \\ ${ }^{2}$ Faculty of Engineering, Cyprus International University, 99010, North Cyprus; TRNC. \\ *Email: Almuhisen.maram@gmail.com; Corresponding Author.
}

\begin{abstract}
For the Jordanian government, meeting the growing demand for goods and services on its own is very difficult, leading to the increased dependence on other sectors of society. This research is aimed at understanding the critical success factors of local public-private partnership projects, identifying the most vital risk factors affecting projects, and establishing a quantitative model for risk assessment. The model can assist public-private partnership contributors by transforming the basic risk assessment principles into a more facilitated and systematic arithmetical based approach. The results showed that the risk factors with the highest ranks (respectively) are transfer phase, organizational risks, financing phase, project management risks, and feasibility study phase. The research is ultimately aimed at developing a framework for the risk evaluation of public-private partnerships within the construction industry in Jordan.
\end{abstract}

Key words: Public-private partnerships, Critical Success Factors, Risk factors, construction, project, Jordan.

\section{INTRODUCTION}

The implementation of Public-Private Partnerships (PPP) has become a major form of contractual organization for projects in developing countries since government budgets are unable to finance large-scale public projects. The foundation of PPPs aims to incorporate public and private resources to promote the efficiency of any project, where project financing is the responsibility of the private sector and risks are properly distributed. Several studies have been conducted on the features of PPPs, such as finance, critical success factors (CSFs), risks, and franchise durations. The success of PPPs depends on the CSFs and risk assessments, which are affected by local strategies and related to the nature and significance of these factors, without neglecting the nature of the project under consideration (Liang et al., 2018). Analysing the probable risk factors throughout all phases of construction projects helps in exploiting revenues and functionality, as well as appropriately developing public facilities/infrastructures while minimizing the difficulties that may arise, particularly in Jordan. PPPs are projects that differ from contracting projects as they not only cover the construction phase of the project, but also the operating phase. However, minimal research on the subject of contract risk assessment for PPPs has been conducted, and there is also a scarcity of researches on the assessment index of PPP projects risks. Despite the various researches on Public-Private Partnerships, there is no consensus regarding a formal definition for PPPs. However, researchers have agreed that PPPs are a contractual affiliation between the private sectors and government establishments to deliver certain services or products to the public sector. Most researches have overlooked PPPs as a technique for the advanced public management concept targeted at regulating government 
agencies towards compelling and productive exploitations

Due to the numerous potential risks, projects are threatened from the initial stage, which may cause investors to abandon the project. Presently, risk assessment is mainly directed towards project contracts (Lin, 2016).

\section{LITERATURE REVIEW}

\subsection{Public-Private Partnerships in Jordan}

In recent years, Jordan has developed from a mainly agricultural society and is rapidly developing in various fields. However, the region has scarce natural resources available and is facing significant economic and environmental challenges(Loewe et al., 2008). As a result, PPPs have gained recognition, as they are considered beneficial since they are the least publicly opposed option for public projects, unlike the different options available such as tool privatization, which requires the permanent transfer of the project ownership from the public sector to the private sector (Al Nasa'a, 2007). To develop the private sector's participation in public projects, Jordan passed a Privatization Law, which came beneficial with the need of major infrastructure demands and the move towards more developed private sector participation in long-term partnerships (Al-Shqairat et al., 2014). The infrastructure sector in Jordan has been the main target for PPP projects as opposed to the services sector. PPP investments can lead to significant risks for developing countries such as Jordan. If managed poorly, a PPP project can lead to potential failure and a waste of large investments. In a country with scarce resources, the failure of such projects can significantly influence the entire development process and deplete valuable resources. Therefore, understanding the process of efficiently managing PPP projects is crucial regarding the efficient utilization of public funds and the development of muchrequired public infrastructure(Mistarihi et al., 2013). There is a consensus among researchers that PPPs are a contractual affiliation between the private sectors and government establishments to deliver certain services or products to the public sector (Wang et al., 2018; Som et al., 2020).

For the past thirty years, PPPs have consisted of several models and offered several diverse services and produces, although there have been examples of significant failure. Currently, PPPs are targeting the modern public management concept of minimizing the government role and intensifying the private sectors in society by attracting private sponsorships for public projects (Wang et al., 2018). PPP structure of private proprietorship and functioning of public facilities has been extensively criticized as a neo-liberal approach that benefits private organizations at the cost of the people and society (Cheng et al., 2021). Many structures for PPPs have emerged based on joint services, roles and liabilities as well as various funding techniques among the government and private sector (Cui et al., 2018; George and Varghese, 2019; dos Santos Prol et al., 2018).

\subsection{Critical Success Factors for PPPs}

Since the 1970s, the Critical Success Factor (CSF) approach has been implemented within economic services as a form of management. CSFs were applied in information systems starting from 1982 and were later implemented in the production industry during the 1900s.

To better understand the factors affecting the success of PPP projects, the CSFs were studied since a large body of research has been devoted to establishing and offering a strategy for CSFs (Ramadhan Mohammed and Harputlugil, 2019). Critical Success Factors are identified as the key areas in which favourable results are necessary to achieve the project objective. (Helmy et 
al., 2020) investigated how CSFs influence the success of PPPs in Egypt. The research explored and identified the CSFs required to assist and ensure the operation of successful PPPs by proposing a CSF model based on an extensive literature review. The researcher was able to determine 21 CSFs and classified them into four categories: political, legal, economic, financial, and operational \& managerial. Quantitative and qualitative analysis utilizing interviews and questionnaires were conducted to obtain the necessary data, which were then analysed using quantitative programs. The results showed that the four CSF groups significantly affect the success of PPPs in Egypt. The study also proposed the environment and conditions required to support PPPs in Egypt.

\subsection{Risk Factors of PPPs}

A fundamental feature of Public-Private Partnerships is risk sharing among the involved parties (public and private sectors).(Liu and Wei, 2018) identified the risk factors influencing PPP projects in China given that they face many risks due to long concession periods, various contributors and other factors associated with PPPs, which lead to failure. The risk factors were identified and analysed by applying a case study on a PPP incineration plant project. The researcher identified 18 risk factors, where the most critical factors included public opposition risk, environmental pollution risk, and government decision-making risk.

It is important to classify risks, as it is a fundamental aspect of any risk management process. The risk factors analysed in this study were classified into 10 groups that cover the entire lifecycle of the project and they are: Feasibility Study, Tendering, Designing, Transfer, Construction, Financial, Procurement, Organizational, Project Management and Operation, and Economic risks. Financing risks evaluates the risks that arise from complications in financing, which are a result of unreasonable financing structure, credit, or national policies. Project Management risks analyses the demand of the project and determines whether the project is in the public interest. The organizational risks evaluate all attributes that affect the execution of PPP projects regarding the employees and other external factors. The transfer phase evaluates the probabilities of transferal delays such as a result of poor conditions, which does not allow for the ongoing operation of the project or the no-transfer of documentations or technology. The feasibility study phase evaluates if a project can be executed under PPP. Table 1 lists the risk factors and sub-factors that were relied on for this study.

Table 1. Risk Factors and Sub-Factors

\begin{tabular}{|l|l|}
\hline Factors & Sub-Factors \\
\hline $\begin{array}{l}\text { Organizational } \\
\text { risks }\end{array}$ & $\begin{array}{l}\text { Changeable cost, duration, scope and quality purpose, Insufficient } \\
\text { organization between team associates, Staff performance, Unsuitable } \\
\text { communication among the association, Unpredictable organizational } \\
\text { construction, and Alteration of the higher management }\end{array}$ \\
\hline Transfer Phase & Failure to complete the transfer and Minimal residual cost \\
\hline $\begin{array}{l}\text { Project } \\
\text { Management Risk }\end{array}$ & $\begin{array}{l}\text { Files and procedures for reducing risk, Discussion of risks among the } \\
\text { project implementation team, Utilization of various project scheduling } \\
\text { methodologies, Alleviation of vital employees at a significant phase } \\
\text { during construction, Unsuitable project feasibility evaluations, } \\
\text { Inadequate predictions regarding economic demands, Efficient } \\
\text { procedure for recognizing project risks }\end{array}$ \\
\hline $\begin{array}{l}\text { Feasibility Study } \\
\text { Phase }\end{array}$ & $\begin{array}{l}\text { Insufficiency in planning, Procurement of land (site), and Extensive } \\
\text { authorization period for the project }\end{array}$ \\
\hline
\end{tabular}




\begin{tabular}{|l|l|}
\hline Financing Phase & $\begin{array}{l}\text { Poor financial attraction for investors regarding the project, Excessive } \\
\text { financial expenses, Unstable interest rates, Regulation alterations, Client } \\
\text { postponement, Increasing employee profits, Increasing cost of resources, } \\
\text { Estimated finance than expected, Alterations within bank bureaucracies } \\
\text { and legislations, Variations of inflation rates }\end{array}$ \\
\hline
\end{tabular}

\section{RESEARCH METHODOLOGY}

\subsection{Complete Research Method}

Initially, the information needed for this research was based on an extensive literature review, which facilitated a better understanding of PPPs. Subsequently, the CSFs that significantly affect local PPPs were identified and analysed through constructive interviews. The collected surveys were examined using different types of software (SPSS, Excel and Super-decisions). Based on the results, the most influential CSFs with the highest rank were determined. To ascertain the important risk factors and sub-factors for local PPP projects, the same procedure used for determining the CSFs was applied. From the obtained data as well as the expertise of five professionals, a hierarchal model for the selection of risk factors was established according to the AHP. The flow of the research methodology is illustrated in Figure 1.

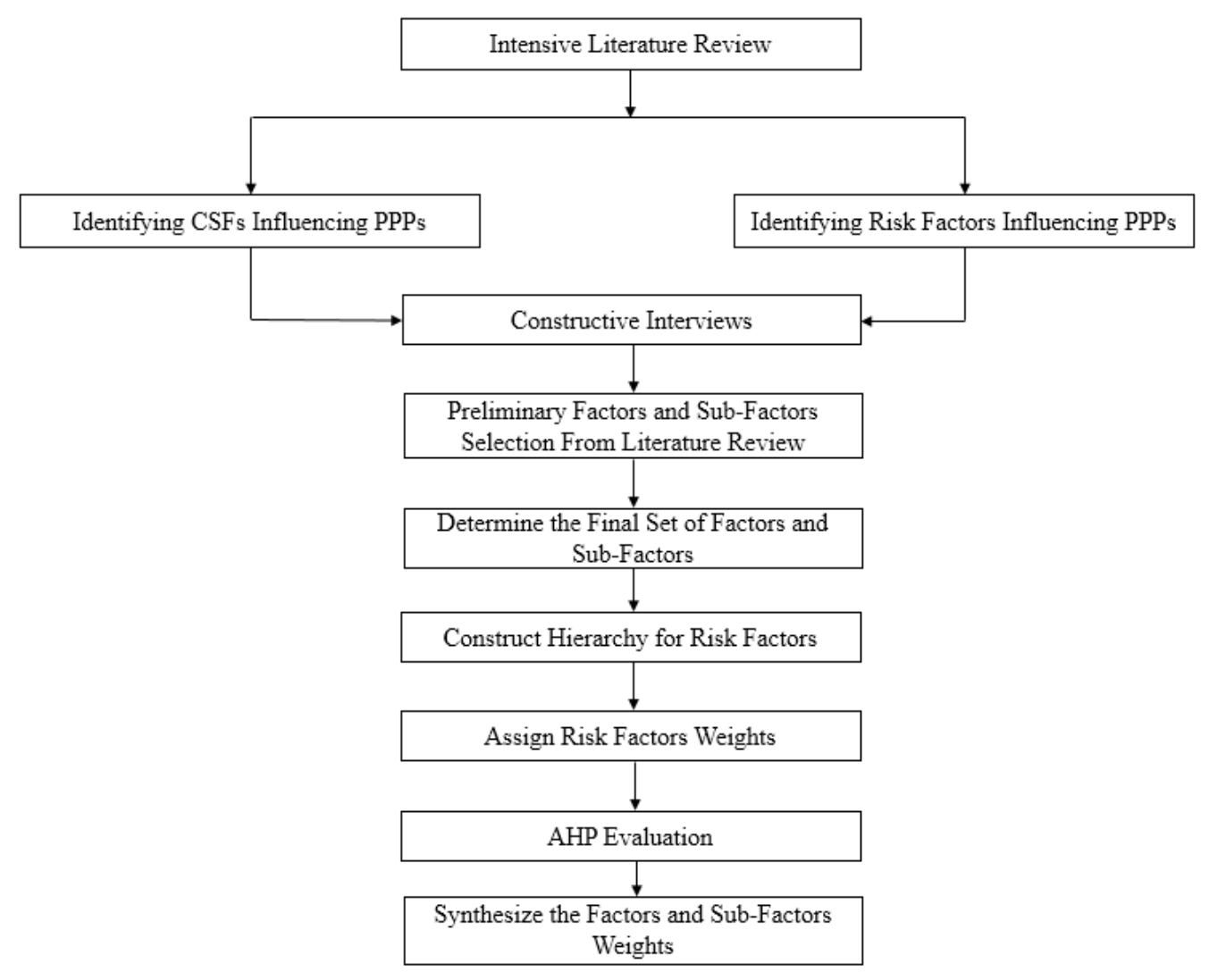

Fig 1. Flow of Research Methodology 


\subsection{Framework of Questionnaires}

Constructive interviews were performed to collect the data needed to complete this study. The first two questionnaires were distributed to 250 respondents. The third questionnaire, which laid the foundation for the risk assessment model applied by the AHP, was only distributed to five experts. Equation 1 was used to determine the sample size:

$$
n=N * \frac{\frac{Z^{2} * \mathrm{p} *(1-\mathrm{p})}{\mathrm{e}^{2}}}{\left[N-1+\frac{Z^{2} * p *(1-p)}{e^{2}}\right]}
$$

Where $\mathrm{n}$ is the sample size, $\mathrm{N}$ is the population size, $\mathrm{Z}$ is the confidence level, $\mathrm{p}$ is the sample proportion and e is the margin of error. For this study, the Z-value was $95 \%$, the population size was 710 , and the margin error was $5 \%$, which resulted in a sample size of 250 .

The interviews were validated by two experts and approved before they occurred. The respondents were required to rate the importance of the factors and sub-factors in terms of the risks influencing PPPs.

The scale used was the linear scale (1-9) developed by Saaty. The respondent's details for the field of work were as follows: Public Sector (32\%), Private Sector (40\%) and others (28\%). The educational field revealed that $(54 \%)$ of the respondents were in the Engineering field, $(20 \%)$ in Business Administration and (26\%) were other fields. The respondents experience were as follows (40\%) had 5-10 years of experience, (22\%) had 10-15 years, and (38\%) has more than 15 years of experience. As for the number of projects managed, $(43 \%)$ of the respondents did not manage a PPP project, $(23 \%)$ managed $1-4$ projects, and (36\%) managed more than five projects.

The final questionnaire was distributed to five Jordanian experts for their rich experience in Public-Private Partnerships and Table (2) reveals the profiles of the selected experts. AHP judgement requires high accuracy and concentration during the evaluation process, therefore, this study relied on the judgements of five experts to ensure the accuracy and avoid any uncertainty during the judgment process. All the experts had relevant knowledge, qualification and work experience of over 15 years in infrastructure projects in Jordan. The outcomes achieved form the foundation for the risk assessment model that was manipulated through the AHP.

Table 2. Profile of the Five Experts

\begin{tabular}{|l|l|l|l|l|}
\hline No. & Role & $\begin{array}{l}\text { Company } \\
\text { Type/Sector }\end{array}$ & $\begin{array}{l}\text { Experience } \\
\text { in the Sector }\end{array}$ & Major Research Fields \\
\hline 1 & Finance Manager & Contractor & $\begin{array}{l}\text { Seventeen } \\
\text { years }\end{array}$ & $\begin{array}{l}\text { Business and Financing } \\
\text { Management }\end{array}$ \\
\hline 2 & $\begin{array}{l}\text { Investment } \\
\text { Manager }\end{array}$ & Contractor & $\begin{array}{l}\text { Eighteen } \\
\text { years }\end{array}$ & Project Investment Management \\
\hline 3 & Project Manager & $\begin{array}{l}\text { Developer } \\
\text { (Public) }\end{array}$ & Fifteen years & Project Management \\
\hline 4 & Professor & $\begin{array}{l}\text { University } \\
\text { (Private) }\end{array}$ & $\begin{array}{l}\text { Twenty-two } \\
\text { years }\end{array}$ & $\begin{array}{l}\text { PPP Project Management and } \\
\text { Construction project }\end{array}$ \\
\hline 5 & Engineer & Contractor & Twenty years & $\begin{array}{l}\text { The complete process in } \\
\text { management projects } \\
\text { infrastructure pros }\end{array}$ \\
\hline
\end{tabular}




\subsection{Framework of Questionnaires}

The Critical Success Factors that greatly influence local PPP projects were selected based on the results of the first questionnaire. Based on the literature review, (19) the main CSFs were identified and analysed using the SPSS statistical method. Table (3) provides the statistical descriptive results, in descending order, for the CSFs according to the respondent's judgements.

Table 3. Statistical Descriptive Figures for Critical Success Factors

\begin{tabular}{|c|c|c|c|c|c|c|}
\hline CSF & RI & Mean & $\begin{array}{l}\text { Std. } \\
\text { Dev. }\end{array}$ & $\begin{array}{l}\text { Perc. } \\
\%\end{array}$ & Rank & $\begin{array}{l}\text { Cronbach } \\
\text { Alpha }\end{array}$ \\
\hline $\begin{array}{l}\text { Proper risk distribution and risk } \\
\text { contribution }\end{array}$ & 0.796 & 3.967 & 0.661 & $79.6 \%$ & 1 & \multirow{19}{*}{0.9033} \\
\hline Constructive Legal Structure & 0.771 & 3.8571 & 0.764 & $77.1 \%$ & 2 & \\
\hline Political Assistance & 0.735 & 3.6735 & 0.851 & $73.5 \%$ & 3 & \\
\hline Decent Governance & 0.722 & 3.6122 & 0.931 & $72.2 \%$ & 4 & \\
\hline Steady Macro-Economic Situation & 0.686 & 3.4286 & 0.890 & $68.6 \%$ & 5 & \\
\hline Comprehensive Economic Strategy & 0.669 & 3.3469 & 0.830 & $66.9 \%$ & 6 & \\
\hline Project Methodological Viability & 0.592 & 2.9592 & 0.706 & $59.2 \%$ & 7 & \\
\hline $\begin{array}{lll}\text { Thorough } & \text { and } & \text { Accurate } \\
\text { Expense/Profit Evaluation } & \end{array}$ & 0.567 & 2.8367 & 0.746 & $56.7 \%$ & 8 & \\
\hline Efficient Public Organization & 0.551 & 2.7551 & 0.751 & $55.1 \%$ & 9 & \\
\hline $\begin{array}{l}\text { Comprehensibility in the Procurement } \\
\text { Procedure }\end{array}$ & 0.539 & 2.6939 & 0.683 & $53.9 \%$ & 10 & \\
\hline $\begin{array}{l}\text { Government Contribution by Offering } \\
\text { Assurances }\end{array}$ & 0.518 & 2.5918 & 0.674 & $51.8 \%$ & 11 & \\
\hline Accessible Economic Market & 0.510 & 2.551 & 0.580 & $51 \%$ & 12 & \\
\hline Compelling Private Association & 0.482 & 2.4082 & 0.574 & $48.2 \%$ & 13 & \\
\hline $\begin{array}{l}\text { Devotion /Accountability of Public } \\
\text { Private Division }\end{array}$ & 0.469 & 2.3469 & 0.561 & $46.9 \%$ & 14 & \\
\hline $\begin{array}{l}\text { United Authorization Among Public } \\
\text { And Private Divisions }\end{array}$ & 0.461 & 2.3061 & 0.466 & $46.1 \%$ & 15 & \\
\hline Technology Allocation & 0.457 & 2.2857 & 0.577 & $45.7 \%$ & 16 & \\
\hline Viable Procurement Procedure & 0.441 & 2.2041 & 0.645 & $44.1 \%$ & 17 & \\
\hline Multiple Advantageous Purposes & 0.424 & 2.1224 & 0.696 & $42.4 \%$ & 18 & \\
\hline Communal Patronage & 0.392 & 1.9592 & 0.706 & $39.2 \%$ & 19 & \\
\hline
\end{tabular}


Considering the statistical perspective, only the factors with a relative importance of $60 \%$ and above are considered. Accordingly, the top Critical Success Factor in Jordan is Proper Risk Distribution and Risk Contribution with a relative importance of 0.796.

The highest-ranking factor, "proper risk distribution and risk contribution", was utilized to lay the foundation for the second questionnaire. The SPSS program was used to determine the most significant risk factors and their sub-factors. Based on the results gathered, the third questionnaire was distributed to a group of experts who were highly proficient in the field of PPP projects, which was manipulated through the AHP. SPSS was applied to analyse the statistical, quantitative, and qualitative data using the following tools: Kolmogorov-Smirnov test of normality, Pearson correlation coefficient for validity, Cronbach's alpha for reliability statistics, frequency and descriptive analysis, stepwise regression and the one-sample t-test. The reliability of the questionnaire was determined by Cronbach's alpha where the values must be 0.897 or above to be acceptable.

\subsection{Risk Identification and Construction of Hierarchy Structure}

A list of 10 risk factors and 60 sub-factors were initially identified according to an extensive literature review, which were sent to professionals for verification and confirmation. The data were evaluated using the SPSS software and the relative index was calculated for the selected factors. The factors with a relative importance of $60 \%$ or higher were chosen. Out of the 10 risk factors, only five were verified and out of the 60 sub-factors, only 17 were verified. The 10 identified factors are listed in Table (4), along with their mean, relative importance index, and standard deviation.

Table 4. Statistical Descriptive Figures of Risk Factors

\begin{tabular}{|c|c|c|c|c|c|c|}
\hline Risk Factors & $\mathbf{R I}$ & $\begin{array}{l}\text { Mean (out of } \\
\text { 5) }\end{array}$ & $\begin{array}{l}\text { Std. } \\
\text { Dev.* }\end{array}$ & $\begin{array}{l}\text { Perc. } \\
\%\end{array}$ & Rank & $\begin{array}{l}\text { Cronbach } \\
\text { Alpha }\end{array}$ \\
\hline Organizational risks & 0.873 & 4.37 & 0.814 & $87 \%$ & 1 & \multirow{10}{*}{0.897} \\
\hline Transfer Phase & 0.86 & 4.29 & 0.71 & $86 \%$ & 2 & \\
\hline $\begin{array}{ll}\text { Project } & \text { Management } \\
\text { Risk } & \end{array}$ & 0.83 & 4.17 & 0.94 & $83 \%$ & 3 & \\
\hline Feasibility Study Phase & 0.81 & 4.03 & 0.92 & $81 \%$ & 4 & \\
\hline Financing Phase & 0.74 & 3.70 & 0.98 & $74 \%$ & 5 & \\
\hline Tendering Phase & 0.57 & 2.87 & 0.622 & $57 \%$ & 6 & \\
\hline Designing Phase & 0.55 & 2.77 & 0.765 & $55 \%$ & 7 & \\
\hline Construction Phase & 0.51 & 2.57 & 0.720 & $51 \%$ & 8 & \\
\hline Operation Phase & 0.49 & 2.47 & 0.67 & $49 \%$ & 9 & \\
\hline Procurement Risks & 0.48 & 2.42 & 0.89 & $48 \%$ & 10 & \\
\hline
\end{tabular}

* Standard deviation is only acknowledged if the value is less than (1)

\subsection{Risk Assessment using AHP}

\section{Step 1: Determining the AHP Judgement Matrices}


The five experts were asked to judge the factors and sub-factors using pair-wise comparison matrices, since factors and sub-factors of risks cannot be measured using the same scale, such as that shown in Equation 2. The consistency of each matrix was checked using Equation 3.

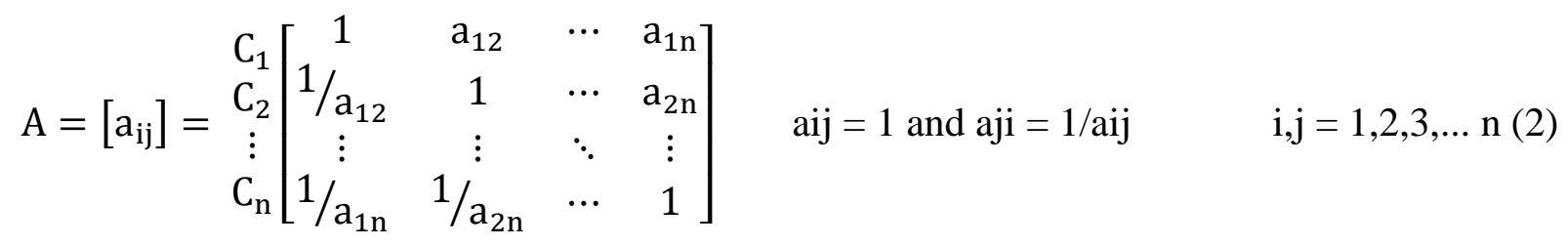

Where $\mathrm{C} 1, \mathrm{C} 2 \ldots \mathrm{Cn}$ indicate the set of factors and (aij) symbolizes a quantified decision-maker judgment on the relative importance for a pair of elements $\mathrm{Ci}$ and $\mathrm{Cj}$ using the fundamental scale, which was developed by Saaty, as shown in Table (5).

$$
\mathrm{CR}=\frac{\mathrm{CI}}{\mathrm{RI}}
$$

Where CR is defined as the consistency ratio, $\mathrm{CI}$ is the consistency index of the matrix, and RI is the random index for the same order matrix.

Table 5. Saaty's fundamental scale(Saaty, 2003)

\begin{tabular}{|l|l|l|}
\hline Scale & Definition & Explanation \\
\hline 1 & Equally Preferred & Two elements equally contribute to the objective \\
\hline 3 & Moderately Preferred & Judgement slightly favor activity C1 over C2 \\
\hline 5 & Strongly Preferred & Judgement strongly favor C1 over C2 \\
\hline 7 & Very Strongly Preferred & Activity C1 is very strongly preferred over C2 \\
\hline 9 & Extremely Preferred & Evidence preferring activity C1 over C2 is evident \\
\hline $2,4,6, \& 8$ & Intermediate Values & When a compromise is needed \\
\hline
\end{tabular}

\section{Step 2: Computing the Weights of the Judgement Matrices}

To calculate the weights, the geometric mean (GM) and normalized weight for each factor and sub-factor shown in Equation 4 and 5 were used, where xi is the entry in the ith row and $n$ is the matrix order.

$$
\begin{aligned}
\mathrm{GM} & =\left(\prod_{\mathrm{i}=1}^{\mathrm{n}} \mathrm{x}_{\mathrm{i}}\right)^{1 / \mathrm{n}} \\
\mathrm{N}_{\mathrm{wi}} & =\frac{\mathrm{GM}_{\mathrm{i}}}{\sum_{\mathrm{I}}^{\mathrm{n}} \mathrm{GM}}
\end{aligned}
$$

Where Nwi is the normalized weight for the row $\mathrm{i}$ and GM is the geometric mean for the $\mathrm{i}-$ th row. To acquire the global weight for a specific sub-factor, Equation (6) will be utilized:

$$
\mathrm{GWji}=\mathrm{GWi} * \mathrm{LWj}
$$


Where GWji is the global weight for sub-factor $\mathrm{j}$ for factor $\mathrm{i}, \mathrm{GWi}$ is the global weight of factor $\mathrm{i}$ and $\mathrm{LWj}$ is the local weight of sub-factor $\mathrm{j}$. Based on the results gathered, the hierarchy for the risk factors assessment model was developed. The hierarchy model is composed of three-levels: the objective, the main factors, and the sub-factors. The factors that received the highest rankings were placed in the structure illustrated in Figure 2.

\section{RESULTS AND FINDINGS}

To develop the risk assessment model, the equations introduced in the previous section were applied. The proposed model is dependent upon the factors and sub-factors that were selected based on the outcomes of the questionnaires. The factors are classified with respect to their local and global weights, which are shown in Table (6).

Table 6. Factors and Sub-Factors Local and Global Weights

\begin{tabular}{|c|c|c|}
\hline Factors and Sub-factors & \begin{tabular}{|l|} 
Local Weights \\
\end{tabular} & Global Weights \\
\hline Transfer Phase & & $48.28 \%$ \\
\hline Failure to Complete Transfer & $45.45 \%$ & $21.94 \%$ \\
\hline Minimal Residual Cost & $9.09 \%$ & $4.38 \%$ \\
\hline $\begin{array}{l}\text { Failure in Managing the Project After Transferring Due } \\
\text { to the Lack of Knowledge Transfer }\end{array}$ & $45.45 \%$ & $21.94 \%$ \\
\hline Organizational risks & & $28.30 \%$ \\
\hline Changeable cost, duration, scope and quality purpose & $10.61 \%$ & $3.00 \%$ \\
\hline Insufficient organization between team associates & $26.04 \%$ & $7.36 \%$ \\
\hline Unsuitable communication within the association & $63.33 \%$ & $17.92 \%$ \\
\hline Financing Phase & & $12.26 \%$ \\
\hline Poor Financial Attraction Towards Investors & $13.30 \%$ & $1.63 \%$ \\
\hline Unstable Interest Rates & $10.91 \%$ & $1.33 \%$ \\
\hline Regulation Alterations & $48.83 \%$ & $5.98 \%$ \\
\hline Increasing Cost of Resources & $6.68 \%$ & $0.81 \%$ \\
\hline Variations of Inflation Rates & $30.05 \%$ & $3.68 \%$ \\
\hline Project Management Risk & & $8.29 \%$ \\
\hline Files and procedures for reducing risk & $26.04 \%$ & $2.15 \%$ \\
\hline Unsuitable project feasibility evaluations & $10.61 \%$ & $0.87 \%$ \\
\hline Efficient procedure for recognizing project risks & $63.33 \%$ & $5.25 \%$ \\
\hline Feasibility Study Phase & & $3.64 \%$ \\
\hline Insufficiency in Planning & $19.31 \%$ & $0.70 \%$ \\
\hline Procurement of Land (Site) & $8.33 \%$ & $0.30 \%$ \\
\hline Extensive Authorization Period for the Project & $72.35 \%$ & $2.63 \%$ \\
\hline
\end{tabular}


The hierarchy of the factors and sub-factors are illustrated in Figure 2.

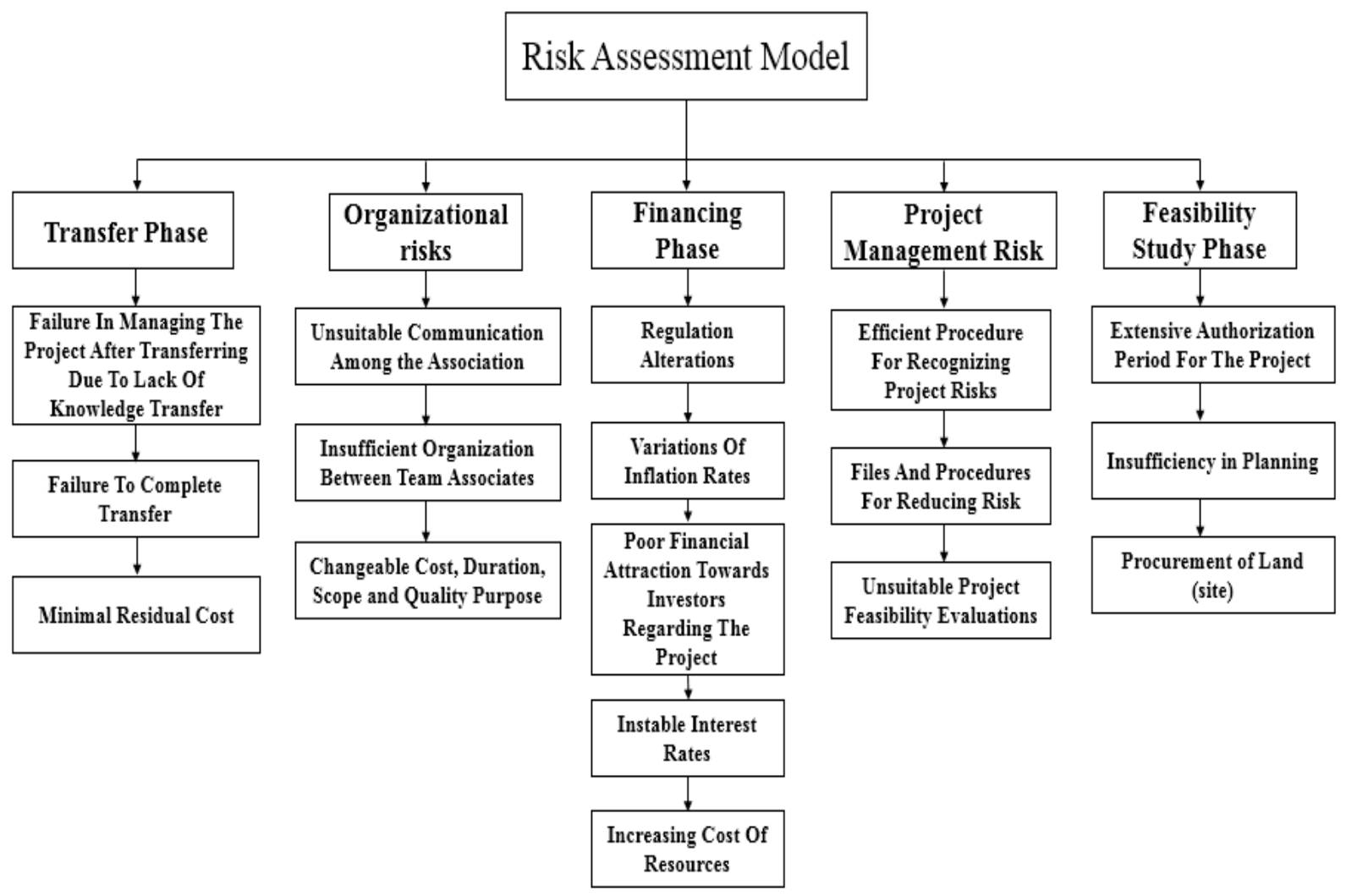

Fig. 2. Risk Assessment Model

The following tables below portrays the results obtained from the pair-wise comparison matrices for the five main factors. The results rely on the scores that the respondents provided through the distributed questionnaires based on the Saaty scale. The following tables, Table $7 \& 8$, will illustrate that.

Table 7. Comparison Matrix for the Main Five Factors

\begin{tabular}{|l|l|l|l|l|l|}
\hline Main Factors & $\begin{array}{l}\text { Feasibility } \\
\text { Study Phase }\end{array}$ & $\begin{array}{l}\text { Financing } \\
\text { Phase }\end{array}$ & $\begin{array}{l}\text { Transfer } \\
\text { Phase }\end{array}$ & $\begin{array}{l}\text { Project } \\
\text { Management } \\
\text { Risks }\end{array}$ & $\begin{array}{l}\text { Organizational } \\
\text { Risks }\end{array}$ \\
\hline $\begin{array}{l}\text { Feasibility Study } \\
\text { Phase }\end{array}$ & $\mathbf{1}$ & $\mathbf{1 / 3}$ & $\mathbf{1 / 9}$ & $\mathbf{1 / 3}$ & $\mathbf{1 / 9}$ \\
\hline Financing Phase & $\mathbf{3}$ & $\mathbf{1}$ & $\mathbf{1 / 5}$ & $\mathbf{3}$ & $\mathbf{1 / 3}$ \\
\hline Transfer Phase & $\mathbf{9}$ & $\mathbf{5}$ & $\mathbf{1}$ & $\mathbf{5}$ & $\mathbf{3}$ \\
\hline $\begin{array}{l}\text { Project Management } \\
\text { Risks }\end{array}$ & $\mathbf{3}$ & $\mathbf{1 / 3}$ & $\mathbf{1 / 5}$ & $\mathbf{1}$ & $\mathbf{1 / 5}$ \\
\hline Organizational Risks & $\mathbf{9}$ & $\mathbf{3}$ & $\mathbf{1 / 3}$ & $\mathbf{5}$ & $\mathbf{1}$ \\
\hline
\end{tabular}

Consistency ratio $(0.0574)$

Critical Consistency Ratio (0.1) 
Table 8. Normalization Matrix for the Main Five Factors

\begin{tabular}{|l|l|l|l|l|l|l|}
\hline Main Factors & $\begin{array}{l}\text { Feasibility } \\
\text { Study } \\
\text { Phase }\end{array}$ & $\begin{array}{l}\text { Financing } \\
\text { Phase }\end{array}$ & $\begin{array}{l}\text { Transfer } \\
\text { Phase }\end{array}$ & $\begin{array}{l}\text { Project } \\
\text { Management } \\
\text { Risks }\end{array}$ & $\begin{array}{l}\text { Organizational } \\
\text { Risks }\end{array}$ & Weight \\
\hline $\begin{array}{l}\text { Feasibility } \\
\text { Study Phase }\end{array}$ & 0.04 & 0.03 & 0.06 & 0.02 & 0.02 & 0.0363 \\
\hline $\begin{array}{l}\text { Financing } \\
\text { Phase }\end{array}$ & 0.12 & 0.10 & 0.11 & 0.21 & 0.07 & 0.1225 \\
\hline Transfer Phase & 0.36 & 0.52 & 0.54 & 0.35 & 0.65 & 0.4828 \\
\hline $\begin{array}{l}\text { Project } \\
\text { Management } \\
\text { Risks }\end{array}$ & 0.12 & 0.03 & 0.11 & 0.11 & 0.04 & 0.0828 \\
\hline $\begin{array}{l}\text { Organizational } \\
\text { Risks }\end{array}$ & 0.36 & 0.031 & 0.18 & 0.35 & 0.22 & 0.2830 \\
\hline
\end{tabular}

The final ranking weight of the main factors was calculated. The main risk factor that obtained the highest rank from the AHP was the transfer phase. It ranked first with a weight of $48.28 \%$, followed by organizational risk with a weight of $28.30 \%$, financing phase $(12.26 \%$ ), project management risks $(8.29 \%)$, and feasibility study phase $(3.64 \%)$.

\section{CONCLUSIONS}

Many studies have been conducted on PPP management, risk evaluation, and the relationship between public and private partners, which have significantly contributed to promoting the implementation of PPP models in various construction projects. However, there is a research gap on these topics for PPP projects in Jordan, especially in the construction sector, and the risk assessment of project implementation. Therefore, it is necessary to study the PPPs in the context of Jordan as well as the factors affecting the success of projects. This paper, to the best of our knowledge, is the first to investigate the CSFs and Risk Factors affecting the successful implementation of PPP projects in Jordan. This paper focused on developing a risk assessment model to evaluate and analyse the most important CSFs and Risk Factors by using the AHP methodology. According to the results gathered, the most influential CSF was proper risk distribution and risk contribution and the most important Risk Factors for PPP projects in Jordan are Transfer Phase, Organizational Risks, Financing Phase, Project Management Risks, and Feasibility Study Phase. When distributing risks among public and private partners, it is preferable to distribute the risks equally to prevent one sector having a higher liability, which also establishes a trust-bond between the two sectors. This research offers the potential to convert such a tool into a software program to become an easily operated expert system. 


\section{REFERENCES}

Al-Shqairat, Z. I., Al Shra'ah, A. E. M., Al-rawad, M. I., \& Al-Kilani, Dm. H. 2014. Assessing the planning of Public Private Partnership (PPP) in E-government implementation experience in Jordan. International Journal of Business and Management, 9(2), 124.

Al-Jaghoub, S., \& Westrup, C. 2003. Jordan and ICT-led development: towards a competition state? Information Technology \& People.

Al Nasa'a, R. 2007. Post occupancy review of comfort conditions at Heelis, central office building for the National Trust. University of London, University College London (United Kingdom).

Cheng, Z., Wang, H., Xiong, W., Zhu, D., \& Cheng, L. 2021. Public-private partnership as a driver of sustainable development: toward a conceptual framework of sustainabilityoriented PPP. Environment, Development and Sustainability, 23(1), 1043-1063.

Cui, C., Liu, Y., Hope, A., \& Wang, J. 2018. Review of studies on the public-private partnerships (PPP) for infrastructure projects. International Journal of Project Management, 36(5), 773-794.

dos Santos Prol, F., de Oliveira Camargo, P., Monico, J. F. G., \& Muella, M. T. de A. H. 2018. Assessment of a TEC calibration procedure by single-frequency PPP. GPS Solutions, $22(2), 35$.

George, J. J., \& Varghese, S. 2019. RISK ASSESSMENT OF PUBLIC PRIVATE PARTNERSHIP PROJECTS IN KERALA.

Helmy, R., Khourshed, N., Wahba, M., \& Bary, A. A. El. 2020. Exploring Critical Success Factors for Public Private Partnership Case Study: The Educational Sector in Egypt. Journal of Open Innovation: Technology, Market, and Complexity, 6(4), 142.

Liang, R., Wu, C., Sheng, Z., \& Wang, X. 2018. Multi-criterion two-sided matching of publicprivate partnership infrastructure projects: Criteria and methods. Sustainability, 10(4), 1178.

Lin, C. 2016. The risk management under conditions of contract for EPC in overseas projects. 2016 International Conference on Logistics, Informatics and Service Sciences (LISS), 1-5. IEEE.

Liu, J., \& Wei, Q. 2018. Risk evaluation of electric vehicle charging infrastructure publicprivate partnership projects in China using fuzzy TOPSIS. Journal of Cleaner Production, $189,211-222$.

Loewe, M., Blume, J., \& Speer, J. 2008. How favoritism affects the business climate: Empirical evidence from Jordan. The Middle East Journal, 62(2), 259-276.

Mistarihi, A., Hutchings, K., \& Shacklock, A. 2013. Differing opinions do not spoil friendships: Managing public-private partnership (PPP) infrastructure projects in Jordan. Public Administration and Development, 33(5), 371-388. 
Ramadhan Mohammed, A. O., \& Harputlugil, T. 2019. Identifying Critical Success and Risk Factors of Airport Projects in Turkey Based on Public-Private Partnership.

Saaty, T. L. (2003). Decision-making with the AHP: Why is the principal eigenvector necessary. European Journal of Operational Research, 145(1), 85-91.

Wang, H., Xiong, W., Wu, G., \& Zhu, D. 2018. Public-private partnership in public administration discipline: A literature review. Public Management Review, 20(2), 293-316. 